\title{
WIESŁAW WRÓBEL
}

Białystok

\section{JESZCZE O POCZĄTKACH STRABLI. UZUPEENIENIA DO BIOGRAFII MACIEJA Z KRAJNY H. TOPÓR (OK. 1470 - 1546)}

Funkcjonujące w literaturze hipotezy dotyczące początków dworu w Strabli ${ }^{1}$ wysnuwane były do tej pory na podstawie analizy treści dokumentu pergaminowego, wystawionego w 1524 r., a obecnie przechowywanego w Archiwum Głównym Akt Dawnych w Warszawie ${ }^{2}$. Uważano, że przywilej ten był jedynym aktem łaski królewskiej wobec Macieja z Krajny zwanego Lisem, a jego przedmiotem były grunta, które w konsekwencji utworzyły dobra strabelskie. Podobnie postąpił także autor tego artykułu, opracowując biogram Macieja ogłoszony w tomie XVIII „Studiów Podlaskich”. Na nowo kwestię początków Strabli otworzył nieznany dotąd dokument, wpisany do 19 księgi zapisów Metryki Litewskiej, wydanej drukiem w 2009 r. w ramach serii Lietuvos Metrika ${ }^{4}$. Dzięki niemu udało się zweryfikować dotychczasowe hipotezy i uszczegółowić biografię Macieja, jak i dzieje jego nadnarwiańskiej siedziby.

$1 \quad$ Z dotychczasowej literatury przedmiotu należy wymienić przede wszystkim: L. Hajdukiewicz, J. Wiśniewski, Maciej z Krajny h. Topór, [w:] Polski Słownik Biograficzny [dalej: PSB], t. XIX, z. 1, Wrocław - Warszawa - Kraków - Gdańsk 1974, s. 21-22; J. Hościłowicz, Zespół pałacowy w Strabli, jego dzieje i konserwacja, „Biuletyn Konserwatorski Województwa Białostockiego” nr 2, Białystok 1996, s. 5-34; J. Maroszek, W. F. Wilczewski, Dzieje obszaru gminy Turośń Kościelna, Turośń Kościelna 1997, s. 6; J. Maroszek, Pogranicze Litwy i Korony w planach króla Zygmunta Augusta. Z historii dziejów realizacji myśli monarszej między Niemnem a Narwią, Białystok 2000, s. 479; M. Sokół, W. Wróbel, Kościót i parafia pw. Bożego Ciała w Surażu. Monografia historyczna do 1939 r., Suraż 2010, s. 43, 67.

2 Archiwum Główne Akt Dawnych w Warszawie [dalej: AGAD], Dokumenty pergaminowe, sygn. 670 .

3 W. Wróbel, Maciej z Krajny i Buzun herbu Topór (ok. 1470 - ok. 1546), „Studia Podlaskie” 2009/2010, t. XVIII, s. 279-296.

4 Lietuvos Metrika, kn. 19, užrašymų knyga 19 (1535-1537), Vilnius 2009, nr 235, s. 239-240. 
Jasność wykładu wymaga przytoczenia w pierwszej kolejności treści dokumentu z 1524 r., decydowała ona bowiem o treści hipotez dotyczących początków Strabli. Na mocy przywileju wystawionego w Krakowie 7 czerwca 1524 r. przez Zygmunta I Starego (na wyraźne polecenie królowej Bony), Maciej z Krajny za wierną służbę lekarską na monarszym dworze otrzymał dwie służby o nazwie Szamolky i Sczohlowsczyna, położone w ziemi bielskiej, województwa podlaskiego. Ponadto nadanie obejmowało prawo do posiadania obu brzegów rzeki Narew (cum ripa utraque fluvii Narew) wraz z możliwością budowy młynów i jazów w jej biegu. Poddanych Macieja zwolniono z wszelkich ciężarów wielkoksiążęcych, on sam natomiast obciążony został obowiązkiem wystawiania z posiadanych dóbr odpowiedniej liczby zbrojnych na wyprawy wojenne. Dokument ten został wpisany do 12 księgi zapisów Metryki Litewskiej ${ }^{5}$.

Próba lokalizacji wymienionych $\mathrm{w}$ dokumencie służb nie natrafiła na przeszkody jedynie względem gruntów określonych mianem Szamolki, których fragmentem była ziemia Molawyczy $y^{6} \mathrm{Z}$ nich bowiem, w wyniku pomiary włócznej przeprowadzonej w połowie XVI w., wykształciły się obecne wsie Samułki i Mulawicze. Nie udało się natomiast zlokalizować służby Sczohlowsczyna. $\mathrm{W}$ związku z tym, że były one położone w bezpośrednim sąsiedztwie późniejszego dworu w Strabli i obejmowały oba brzegi rzeki Narew, oczywiste wydało się historykom, że nadanie to stanowiło podstawę pod organizację przyszłych dóbr strabelskich.

Weryfikację powyższych hipotez przyniósł wspomniany we wstępie dokument, wpisany do 19 księgi zapisów Metryki Litewskiej. Przyjrzyjmy się bliżej jego treści. 24 lipca 1536 r. przed królem Zygmuntem I Starym stanął osobiście Maciej Lis, przedkładając władcy wystawiony 12 lat wcześniej przywilej. Po dokładnym

Lietuvos Metrika, kn. 12, užrašymų knyga 12 (1522-1529), Vilnius 2001, nr 738, s. 579-580.

6 Naszą wiedzę warto w tym miejscu uzupełnić o dodatkowe informacje. W przywileju nadawczym Zygmunta I wzmiankowany był szlachetny Jan Warpoch, który zajął opuszczoną część gruntów przynależnych do służby Molawycza (tertia parte deserta et nunc occupata per nobilem Ioannem Varpoch). Nie wiemy, w jaki sposób Warpoch uzyskał omawiane tu grunta, ale najprawdopodobniej usunięcie jego z gruntów nad Narwią wywołało w nim strach przed ewentualnością utraty kolejnych swych majętności. 18 lipca 1524 r., a więc w niespełna miesiąc od wydania przez Zygmunta I Starego opisanego wyżej przywileju na rzecz Macieja z Krajny, szlachcic powiatu bełskiego, Jan Warpoch, stanął przed obliczem królewskim w Krakowie i prosił monarchę o potwierdzenie dotychczasowego stanu posiadania. Zygmunt I przychylił się do jego prośby i potwierdził dokumentem wszystkie posiadane przez Warpocha ziemie, tj. Hłodczynę i Kudowszczynę, położone w powiecie Bielskim, a nadane mu przez Mikołaja Mikołajewicza Radziwiłła i potwierdzone listem króla Aleksandra. Dokument królewski wpisany do 12 księgi zapisów Metryki Litewskiej: Lietuvos Metrika, kn. 12 [12], nr 364, s. 312-313. Jan Warpoch wzmiankowany w: A. Boniecki, Poczet rodów w Wielkim Księstwie Litewskim w XV i XVI wieku, Warszawa 1887, s. 362. 
opisaniu jego treści, przede wszystkim zaś omówieniu wolności, jakich zażywał Maciej korzystając z nadanych mu w 1524 r. służb, w dokumencie odnotowano: и биль намь чоломь, аж быхмо тыи земгли вышеи писаныи ему даныи, на

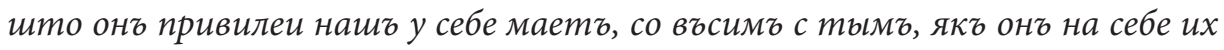
держаль, к рукамъ нашимг г(о)с(по)д(а)ргским взяли и къ замку Бельскому их привернути казали, а ему напротивъку того инбшыи земъли, такъжо з оными вольностьми водле оного привиля, котови онъ перед нами положиль и крукамъ нашымъ его даль, у повете Бельскомъ дали, о чомъ жо и королевая

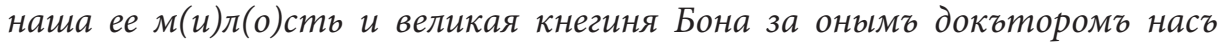
жедала. Mamy więc do czynienia z sytuacją, w której Maciej z Krajny, z niewyjaśnionych do końca przyczyn, prosił króla, aby odebrał od niego nadane wcześniej służby, w zamian dając inne, również położone w ziemi bielskiej. Niewykluczone, że decydującą rolę w działaniach królewskiego lekarza odegrał spór o granice pomiędzy jego dobrami a gruntami należącymi do prepozytury w Bielsku, rozstrzygnięty przez Zygmunta I Starego 21 czerwca 1536 r. na korzyść bielskiego proboszcza, ks. Sebastiana Branickiego, wówczas już biskupa-elekta kamienieckiego ${ }^{7}$.

Jak informuje dokument z 1536 r., król przychylił się do prośby swego dworzanina, a odebrawszy dotychczasowe posiadłości wraz z pergaminem z 1524 r. ${ }^{8}$, nadał mu dwie nowe ziemie. Pierwsza z nich, określana mianem Brykowszczyzna, przynależała do włości miasta Bielska. Do tego czasu gospodarzył na niej mieszczanin o imieniu Bryk, którego król росказали (...) прочв знести, а на инбшои земъли нашои его осадити. Druga ziemia, Rogaczyzna, znajdowała się w momencie nadania $w$ rękach królewskich. Ekwiwalent obejmował poza gruntami w zasadzie te same przywileje, a więc wszystkich poddanych żyjących na obu służbach, dziakło, daniny miodowe i groszowe wraz ze wszystkimi innymi daninami i czynszami, wreszcie, podobnie jak w 1524 r., oba brzegi rzeki Narew z prawem budowy młynów i jazów. Maciej i jego nowi poddani zostali uwolnieni od wszelkich powinności miejskich i ziemskich oraz z robót grodowych w Bielsku,

7 Archiwum Państwowe w Krakowie, Zbiór Zygmunta Glogera, sygn. 680, s. 14; K. R. Prokop, Biskupi kamienieccy od średniowiecza do współczesności. Szkice biograficzne, Biały Dunajec - Ostróg 2007, s. 83.

8 Wyjaśnia to jednocześnie drogę, jaką przywilej ziemski Macieja z Krajny trafił z rąk prywatnych najpierw do Archiwum Wielkoksiążęcego, a po 1569 r. do Archiwum Koronnego, por:: AGAD, Varia Oddziału I, sygn. 57, k. 167 (Littera pallatinatus Podlachia. (...) No. 72. Sigismundus rex Mathias Krayna de Buszyn Physico suo iure perpetuo duo servitia et duas terras alterum Samolki alterum Scoclowczyna in districtu Bielscensis cum ripa Narew donat. Cracoviae feria 3 ante festum S. Barnaba Apostoli anno 1524). 
Brańsku i Surażu, zaś w sądownictwie mieli podlegać pod polskie prawo ziemskie, funkcjonujące w ziemi bielskiej.

Przejęcie przez króla dóbr nadanych Maciejowi z Krajny w 1524 r. podważa dotychczasowe ustalenia dotyczące początków dóbr strabelskich. Wpis w 19 księdze Metryki Litewskiej upoważnia nas do przesunięcia daty początków nadnarwiańskiej włości na lata po $1536 \mathrm{r}$. W przekonaniu tym utwierdza nas nowa klauzula zawarta w przywileju z 1536 r., nieujęta w treści dokumentu z 1524 r., która zezwalała lekarzowi królewskiemu na swobodny przewóz towarów przez Narew. Najwidoczniej Maciej skorzystał z nowego prawa, skoro jego spadkobiercy z rodu Arciechowskich dysponowali własną przeprawą mostową. Po raz pierwszy wzmiankowana była ona w 1574 r., kiedy to Benigna Dziadkowska z Turośni skarżyła się przed sądem grodzkim brańskim na wnuka Macieja z Krajny, Feliksa Arciechowskiego, że ten zaniedbuje należący do niego most, nie chce go reperować ani się nim opiekować, co nie przeszkadzało mu w pobieraniu podatku mostowego (de eo, quia ipse pontem suum in fluvio Narew existens malum habet et illum reparare non vult, neque curat et pontalia capit ubi malus transitus est $)^{9}$.

Nie powinno w takim razie ulegać wątpliwości, że dopiero zamiana gruntów dokonana przez Zygmunta I Starego w 1536 r. dała początek właściwym dobrom strabelskim. Strabla (Strablya) pojawia się po raz pierwszy w źródłach pod rokiem 1555 jako własność Mikołaja Arciechowskiego ${ }^{10}$, wojskiego bielskiego (1554-1567) ${ }^{11}$ i zięcia Macieja, możemy więc założyć, że tamtejszy dwór powstał pomiędzy 1536 a 1555 r. Dobra strabelskie w ciągu kilku następnych dziesięcioleci zostały zaopatrzone w odpowiednią „infrastrukturę" gospodarczą. W 1577 r. wspomniany Feliks Arciechowski opłacił podatek łanowy $z$ imion swoich naprzód $z$ imienia [Strabla] $z$ włók 41ำ osiadtych po groszy 20 a od ogrodników 3 po groszy 4. Item imienia Łapcow włók osiadlych 541⁄2 po groszy 20, item zimienia Molawicz z włók osiadłych 31/4 po groszy 20, a od ogrodników 3 po groszy 4 , a także za 4 dziedziczne i 2 doroczne koła młyńskie ${ }^{12}$, wreszcie od 2 karczm dorocznych $^{13}$. Do tego wszystkiego należy dodać wspomniany już most na rzece

9 AGAD, Księgi grodzkie brańskie, sygn. 6, k. 429v.

10 Centralne Państwowe Archiwum Historyczne Białorusi w Mińsku, f. 1708, op. 1, d. 2, k. 12.

11 Urzędnicy Podlascy XIV-XVIII w. Spisy, oprac. E. Dubas-Urwanowicz, W. Jarmolik, M. Kulecki, J. Urwanowicz, Kórnik 1994, nr 288, s. 61.

12 W 1591 r. rejestr poborowy wymienił tylko dwa koła młyńskie, A. Jabłonowski, Polska XVI wieku pod względem geograficzno-statystycznym, t. 6: Podlasie, cz. 1, Warszawa 1908, s. 153.

13 AGAD, Archiwum Skarbu Koronnego, Oddział I, sygn. 47, k. 237, 238v, 240v. 
Narew. W 1556 r. Mikołaj Arciechowski zobowiązany był do wystawiania trzech koni ex bonis coniugis suae nobilis Barbara filia olim egregii Mathiae Lyss physici sacrae regiae maiestatis de Strabla et aliis bonis ${ }^{14}$. W popisie ziemian bielskich z 1565 r. wojski wystawił 4 konie 3 ыменья матерыстого Страбли, з Лесне, з Бузин (... $)^{15}$. Mikołaj żył jeszcze w pierwszej połowie $1567 \mathrm{r}^{16}$, ale już w październiku tego roku, na kolejnym popisie ziemian bielskich stawił się jego syn, Feliks Zbożny (Aukt) wraz z 7 końmi ${ }^{17}$. On też z dóbr strabelskich w 1569 r. składał przysięgę na wierność Koronie ${ }^{18}$.

$\mathrm{Na}$ marginesie rozważań na temat początków Strabli warto zwrócić uwagę na nieznane dotąd szczegóły z dziejów wsi Samułki, a zarazem i prepozytury w Bielsku. Odebrana w 1536 r. służba Samolky pozostawała w rękach monarszych do 1561 r. Przeprowadzona rok wcześniej przez mierniczego Stanisława Skoczka Dziewiałtowskiego pomiara włóczna przekształciła ją w wieś nowego typu, ze skoncentrowanym, ulicowym układem gospodarstw i trójpodziałem pól.

Rozmierzanie na nowo podlaskich królewszczyzn doprowadziło do przesunięć istniejących granic i jednoczesnego naruszenia, niekiedy w znacznym stopniu, dotychczasowego stanu posiadania zarówno osób świeckich, jak i duchownych. W wielu przypadkach do króla trafiały skargi dotyczące nowych podziałów własnościowych lub niesprawiedliwych rekompensat (w przypadku konfiskaty lub tzw. odmian), czego przykładem może być chociażby powtórna pomiara Suraża, przeprowadzona w 1562 r. na osobistą prośbę mieszczan wystosowaną do Zygmunta Augusta lub skargi Stanisława Włoszka z Juchnowca o przyłączenie jego gruntów do starościńskiej wsi Pomigacze ${ }^{19}$. Wówczas zamianie poddane zostały także grunta suraskiego kościoła parafialnego. Podobna sytuacja zaistniała w $1560 \mathrm{r}$. w przypadku pomiary gruntów Bielska, kiedy to na potrzeby mieszczan Dziewiałtowski przejął część ziem należących do bielskiej prepozytury, zarządzanej w latach ok. 1560-1575 przez ks. Jana Pikarskiego, dziekana warszaw-

14 AGAD, Kapicjana, p. 9, s. 117-118.

15 Русская Историческая Библиотека, t. XXXIII (Литовская Метрика, отделъ первый, часть третья: Книги Публичныхъ Дэлъ. Переписи войска Литовскаго), Petersburg 1915, szp. 368. Wymieniona w dokumencie Leśna to najprawdopodobniej wieś szlachecka w parafii Suraż, której fragment musieli posiadać Arciechowscy.

16 Urzędnicy Podlascy..., nr 288, s. 61.

17 Русская Историческая Библиотека..., szp. 1096.

18 Akta unii Polski z Litwą 1385-1791, wyd. S. Kutrzeba, W. Semkowicz, Kraków 1932, s. 257.

19 Писиовая книга гродненской економіи съ прибавленіами, t. 2, Wilno 1882, s. 413, 453, 520-521. 
skiego i plebana nowogródzkiego ${ }^{20}$. W ramach rekompensaty utraconych ziem Piotr Chwalczewski, główny ekonom Wielkiego Księstwa Litewskiego kierujący pomiarą włócznąa ${ }^{21}$ rozkazał przydzielić kościołowi bielskiemu nowe ziemie. Nadanie objęło rozmierzoną wieś Samułki o powierzchni wynoszącej 22 włóki i 15 morgów, wraz z brzegiem Narwi. Ksiądz Pikarski przedstawił przed królem Zygmuntem Augustem dokument Piotra Chwalczewskiego, którego treść monarcha potwierdził w całości, wystawiając na rzecz duchownego przywilej, datowany 9 lutego 1561 r. w Wilnie ${ }^{22}$.

W wyniku zamiany dokonanej przez Chwalczewskiego dawna własność Macieja z Krajny stała się częścią uposażenia prepozytury w Bielsku Podlaskim.

\section{More on the origin of Strabla. A complementary biography of Maciej of Krajna of Hatchet coat of arms (app. 1470 - 1546)}

\section{Summary}

The article supplements a biography of the Jagiellonian court physician - Maciej of Krajna, of Hatchet coat of arms, also called Fox, which appeared in the eighteenth volume of "Podlasie Studies". A document, which has been unknown until now, issued in 1536, under which the king Sigmund Old deprived Maciej of services that he had been awarded with in 1524 (Szamolky and Sczohlowsczyna) and conferred him with the new ones in exchange (Brykowszczyzna and Rogaczyna), which covered the same rights and immunities, appeared in print in the 19th book of the Lithuanian Metrica' notes. The content of this document compels us to change a date of the Strabla court and estates foundation to the years between 1536 and 1555. What is more, a new privilege contained a clause allowing free transport of goods across the Narew river. Exercising this right, Maciej of Krajna erected a bridge across the river which was used by his descendants. It was mentioned for the first time in 1577

20 A. Sołtan, Pikarski (mylnie Piekarski) Jan h. Półkozic (1516-1577), PSB, t. XXVI, 1981, s. 222-223; V. Ališauskas, T. Jaszczołt, L. Jovaiša, M. Paknys, Lietuvos kataliku dvasininkai XIV-XVI a., Vilnius 2009, nr 918, s. 159-160.

21 L. Kolankowski, Pomiara włóczna, „Ateneum Wileńskie” 1927, z. 2, s. 241-242.

22 Dokument został wpisany do ksiąg konsystorskich biskupstwa łuckiego: Archiwum Diecezjalne w Siedlcach, D 152, k. 47v-48v. Za wskazanie tego dokumentu autor składa podziękowania dr. Tomaszowi Jaszczołtowi. 
when Benigna Dziadkowska complained before the court that Maciejs grandson, Feliks Arciechowski did not look after the passage in his possession. The Szamolky service, which the court physician was deprived of in 1536 and which is identified as a contemporary village Samułki, was conferred to provostry in Bielsk Podlaski as part of compensation for the lands lost during the 1560 Wallach reform of the city of Bielsk.

\section{Ещё о зачатках Страбли. Дополнения в биографию Матвея из Крайны, герб Топор (около 1470 - 1546)}

\section{Резюме}

Статья это дополнение биографии придворного врача Ягеллонов, Матвея из Крайны, герб Топор, называемого Лисой, которая было напечатана в XVIII томе „Подляских исследований”. В печатном издании 19 книги записей Литовской Метрики помещен неизвестный до сих пор документ, выставленный в 1536 г., согласно которому король Сигизмунд Старый забрал пожалованные Матвею в 1524 г. имения (Szamolky и Sczohlowsczyna) и взамен пожаловал новые (Brykowszczyzna и Rogaczyna), пользующиеся теми же правами и иммунитетами. Содержание этого документа заставляет передвинуть дату основания двора и поместий Страбля на годы между 1536 и 1555. Кроме того, в новой привилегии нашлась клаузула, разрешающая на свободную перевозку товаров через реку Нарев. Пользуясь этим правом, Матвей из Крайны построил на реке мост, которым пользовались его потомки. Впервые он упоминается в 1577 г., когда Бенигна Дядковская жаловалась в суде, что внук Матвея, Феликс Арцеховский, не заботится о бывшей в его владении переправе. Отнятое королевскому врачу в 1536 г. имение Szamolky, идентифицирована как современная деревня Самулки, в 1562 г. было пожаловано препозитуре в Бельске Подляском, в порядке компенсации за земли, потерянные во время проведенного в 1560 г. волочного измерения города Бельска. 